\title{
Laceração peniana em cavalo Mangalarga Marchador - relato de caso
}

[a] Universidade Estadual Paulista (UNESP), Guarapuava, PR, Brasil

[b] Universidade Estadual Paulista (UNESP), Guarapuava, PR, Brasil

*Autor correspondente

e-mail: carlafredrichsen@yahoo.com.br

\section{Resumo}

Foi atendido um garanhão, 4 anos de idade, Mangalarga Marchador, com queixa de lesão peniana. 0 proprietário relatou que o animal havia ferido o pênis em cerca de arame liso há duas semanas. 0 paciente foi medicado com benzilpenicilina associada à estreptomicina, com terapia antinflamatória à base de dexametasona, durante três dias consecutivos, sem melhora clínica. 0 animal era mantido em pastagem com duas fêmeas saudáveis, recebia ração e suplemento mineral no cocho, água ad libitum oriunda de represa e foi vacinado contra tétano, influenza e encefalite viral. Ao exame físico, observou-se dor intensa e edema em prepúcio que dificultava exposição do pênis. Foi necessária administração de acepromazina para avaliação do órgão. A laceração estendia-se da porção dorsal até a ventral do corpo do pênis, recoberta por áreas de necrose, odor fétido e sangramento, não sendo detectadas outras alterações clínicas. Foi realizado hemograma, não sendo observadas alterações nos parâmetros hematológicos. 0 animal permaneceu internado e o tratamento preconizado foi administração de flunixim meglumine 1,1 mg/Kg IV e omeprazol $2 \mathrm{mg} / \mathrm{kg}$ VO a cada 24 horas, durante 5 dias consecutivos, e curativo local. Este era precedido de ducha fria no prepúcio, seguida de massagem com DMSO em gel e spray repelente ao redor. 0 pênis era exposto para limpeza da ferida com gaze embebida em solução fisiológica, seguida pela aplicação de pomada à base de clorexidine; procedimento realizado a cada 12 horas, durante 45 dias. No segundo dia de tratamento observou-se diminuição do edema e, após cinco dias, o animal já expunha o pênis para urinar, com completa cicatrização ao final do tratamento, quando recebeu alta hospitalar.

Palavras-chave: Fisiopatologia. Reprodução. Enfermidade peniana. 